University of Nebraska - Lincoln

DigitalCommons@University of Nebraska - Lincoln

Nebraska Cooperative Fish \& Wildlife Research Nebraska Cooperative Fish \& Wildlife Research Unit -- Staff Publications

$1-1-2020$

\title{
Exit here: strategies for dealing with aging dams and reservoirs
}

\author{
Henry H. Hansen \\ University of Nebraska-Lincoln \& Leibniz-Institute of Freshwater, Ecology and Inland Fisheries, \\ henry.hansen@igb-berlin.de \\ Emily Forzono \\ University of Nebraska-Lincoln \\ Alisha Grams \\ University of Nebraska-Lincoln \\ Lindsay Ohlman \\ University of Nebraska-Lincoln \\ Christine Ruskamp \\ University of Nebraska-Lincoln
}

See next page for additional authors

Follow this and additional works at: https://digitalcommons.unl.edu/ncfwrustaff

Part of the Aquaculture and Fisheries Commons, Environmental Indicators and Impact Assessment Commons, Environmental Monitoring Commons, Natural Resource Economics Commons, Natural Resources and Conservation Commons, and the Water Resource Management Commons

Hansen, Henry H.; Forzono, Emily; Grams, Alisha; Ohlman, Lindsay; Ruskamp, Christine; Pegg, Mark A.; and Pope, Kevin L., "Exit here: strategies for dealing with aging dams and reservoirs" (2020). Nebraska Cooperative Fish \& Wildlife Research Unit -- Staff Publications. 306.

https://digitalcommons.unl.edu/ncfwrustaff/306

This Article is brought to you for free and open access by the Nebraska Cooperative Fish \& Wildlife Research Unit at DigitalCommons@University of Nebraska - Lincoln. It has been accepted for inclusion in Nebraska Cooperative Fish \& Wildlife Research Unit -- Staff Publications by an authorized administrator of DigitalCommons@University of Nebraska - Lincoln. 


\section{Authors}

Henry H. Hansen, Emily Forzono, Alisha Grams, Lindsay Ohlman, Christine Ruskamp, Mark A. Pegg, and Kevin L. Pope 


\title{
Exit here: strategies for dealing with aging dams and reservoirs
}

\author{
Henry H. Hansen ${ }^{1,3}$ (E) Emily Forzono ${ }^{1} \cdot$ Alisha Grams $^{1} \cdot$ Lindsay OhIman $^{1} \cdot$ Christine Ruskamp $^{1} \cdot$ Mark A. Pegg ${ }^{1}$. \\ Kevin L. Pope ${ }^{2}$
}

Received: 23 July 2018 / Accepted: 15 October 2019 / Published online: 22 October 2019

(c) Springer Nature Switzerland AG 2019

\begin{abstract}
Aging infrastructure is prevalent throughout the world, but water control management structures, specifically dams, are of growing concern. Dams and their corresponding reservoirs have inherent, but separate, lifespans. The proportion of dams around the world that continue operation beyond their intended lifespans is growing at an alarming rate. Society will not only have to navigate the tradeoffs associated with the deterioration of services provided by reservoirs and dams, but also impending structural failures. Society is nearing a critical pinch point where we will have to decide how to deal with dams and reservoirs at scales that range from a single system to multiple systems in large watersheds. No comprehensive strategy exists to inform both the range of actions that can be applied to such infrastructure and how such actions would influence biophysical, socioeconomic, and geopolitical tradeoffs. The development of proactive exit strategies is a critical first step in ensuring controlled transitions for aging dams and reservoirs. Herein, we present an overview of actions and considerations for aging dams and reservoirs, followed by an initial framework for exit strategy development to launch a further discussion on how society could deal with this aging infrastructure.
\end{abstract}

Keywords Dams $\cdot$ Reservoirs $\cdot$ Rivers $\cdot$ Aging $\cdot$ Exit strategy $\cdot$ Conceptual framework

\section{Introduction}

Dams and their associated reservoirs continue to be a prominent feature of the human enterprise (Fahlbusch 2009; Graf 1999), yet the negligence of addressing aging dams and reservoirs has become pervasive. A review of the 2018 National Inventory of Dams lists approximately 90,000 dams in the United States of America (USA) with the vast majority being built within the last century (inventory only includes dams 1.8 meters in height or greater) (U.S. Army Corps of Engineers 2018). Many of the dams built prior to the 1970s are near or beyond their life expectancy because they were

Henry H. Hansen

henry.hansen@igb-berlin.de

1 School of Natural Resources, University of Nebraska, Lincoln, NE, USA

2 U.S. Geological Survey-Nebraska Cooperative Fish and Wildlife Research Unit and School of Natural Resources, University of Nebraska, Lincoln, NE, USA

3 Department of Biology and Ecology of Fishes, Leibniz-Institute of Freshwater Ecology and Inland Fisheries (IGB), Berlin, Germany engineered with an expected lifespan of 50 years (Juracek $2015)$ which accounts for approximately $53 \%(48,516)$ of dams in the USA (U.S. Army Corps of Engineers 2018) (Fig. 1). Moreover, there were typically no plans in place regarding how to deal with dams and their associated reservoirs beyond the end of this projected life-span when these structures were first built. The potential consequences of dam failure include severe financial costs through loss of physical property and land productivity as well as the loss of human life. The relatively recent structural failure of the Oroville Dam spillway, California, USA illustrates these implications with the evacuation of nearly 200,000 residents at an estimated emergency response and recovery effort cost of over \$1 billion (Bea 2017; California Department of Water Resources 2018). The American Society of Civil Engineers (1997) Report Card identified that within the USA, 15,948 dams (17\%) are currently recognized as being a high hazard potential, meaning if a failure were to occur there would be the probable loss of human life coupled with economic losses and environmental damage. Reports from the Association of State Dam Safety Officials (2019) and National Performance of Dams Program (2017) indicate that catastrophic dam failures have not been eliminated at 




Fig. 1 Average age of dams (years) per 10,000 km² hexagon across the United States of America. Data for dams were derived from $\mathrm{R}$ package "dams" (Goteti and Stachelek 2016) and mapped using Esri

a national level. The American Society of Civil Engineers estimated that at least $\$ 64$ billion (USD) are needed to rehabilitate the nation's non-federal and federal dams, but only about $\$ 6$ billion is provided through the Water Infrastructure Improvements for the Nation Act 2016 (Diloreto et al. 2017). Emergency Action Plans are an approach to minimize losses associated with failures for dams, but such plans are not mandatory in all instances, and some management organizations that are required to make such plans have neglected to do so (Federal Emergency Management Agency 2007). Many corresponding reservoirs to these aging dams are also approaching the end of their lifespan. Miranda and Krogman (2015) reported the average $( \pm S D)$ functional age (position along life span) of reservoirs in the USA was $71 \pm 1$ years. The consequences of reservoir aging are chronic and generally ignored compared to acute structural failures associated with dams, which are more often addressed.

Regardless of size, the range of functions for which dams were built provides ecosystem services necessary for societal function (e.g., water supply, irrigation for agriculture, electricity), making dams difficult to substitute or replace with alternative infrastructure (Poff and Hart 2002). For
ArcMap 10.6. Analysis involved overlaying the entirety of the USA with a hexagonal grid where each hexagon was used to calculate an average age of intersecting dams

example, approximately 3700 proposed or under construction hydropower dams across multiple developing countries are expected to increase global hydropower production by $73 \%$ as of 2014 (Zarfl et al. 2015). Increasing populations in developing countries will require more water to support the societal demands of agricultural, industrial, energy, and environmental sectors (Biswas and Tortajada 2001). Therefore, consideration and response to the aging processes for both the dam and its reservoir are paramount in sustaining services. The most basic definition of physical aging is the deteriorative process of functional properties. Physical aging is the process that controls structural life spans, and it should not be misinterpreted for economic lifespans. Economic life spans focus only on the costs and benefits associated with the operations and management of a structure (Palmieri et al. 2001). Structural life spans always exceed economic life spans, and consequently, often lack the necessary financial resources to manage the structure adequately when the economic life span has ceased. For a dam, physical aging applies to its structural integrity and operation (ZamarrónMieza et al. 2017) and for a reservoir, its storage capacity (Juracek 2015). The structural integrity of a dam will largely 
depend on dam type, topography, hydrology, sedimentation, and geology (American Society of Civil Engineers Task Committee 1997; Peyras et al. 2006). Additionally, the function, construction material, special structural design, and hydraulic design of a dam all influence aging (Foster et al. 2000; Siddiqui 2009). For example, sulfate or alkali reactions between water chemistry and concrete age a concrete dam differently than the freezing and thawing mechanisms acting on an earthen dam (Dolen 2005). From an operational perspective, a dam's foundation, body, and appurtenant works (e.g., gates, spillways) are separate components that can age independently of one another (Sims 1992).

Reservoirs have life expectancies in which they are predicted to maintain a certain level of function for an estimated length of time. That lifespan can change through inreservoir mitigation or watershed changes; however, an end point will eventually be reached for the reservoir. Physical and chemical weathering from flowing water and precipitation facilitate the reservoir aging process (Datta and Tyagi 1996). When combined with the impacts from anthropogenic activities (e.g., development, pollution) the degradation of a reservoir is accelerated (Tang et al. 2005) resulting in water storage depletion and additional habitat alterations (Juracek 2015; Pegg et al. 2015; Poff and Hart 2002). If left unmanaged, sedimentation may result in a lacustrine-like reservoir changing into a wetland habitat rendering the reservoir incapable of providing intended anthropogenic and ecosystem services (Juracek 2015). Prolonged sedimentation can result in cascading effects of nutrient changes resulting in shifts of biological communities, increased algal blooms, and occurrence of fish kills (Johnson et al. 2008; Chunlong et al. 2017). Basin filling by siltation will also impair provisioning services such as recreation and drinking water that depend on a non-eutrophic system (Kimmel and Groeger 1983; Pegg et al. 2015). For both dams and reservoirs, the aging processes can be slowed, but cannot be stopped.

The most challenging aspect regarding timelines associated with aging of dams and reservoirs is estimating the real expiration date for each component. For dams, this is generally executed through risk analysis and failure modeling; whereas for reservoirs, this is done through modeling of sediment accumulation. Such methods are often implemented in a piecemeal fashion and generally lack the integration of stakeholders and regulatory interests (Gagnon et al. 2002). Given the timelines are not necessarily congruent, stakeholders need a flexible, yet implementable exit strategy to proactively manage the aging processes and allow ideal transitions before components expire. Additionally, the strategy should also be flexible to accommodate the single or multiple purposes a dam may serve, such as irrigation, hydropower, water supply for domestic and industrial use, inland navigation, or flood control (Billington et al. 2005; World Commission on Dams 2000). We contend that having a proactive approach with known practices that are ready for implementation will be more cost-effective, facilitate collaboration among stakeholders, and allow proper planning that is desperately needed in this situation (Ho et al. 2017). Ultimately, a time will come when the function of a dam and its associated reservoir will no longer be viable. This end point should culminate in a well-developed and sensible plan that allows for an "exit" from the status quo that is sensible not just for the infrastructure in question but also for the broader socio-ecological system. The entire process can be characterized as an "exit strategy" to facilitate both short- and long-term oversights of these aspects of aging infrastructure (Doyle et al. 2008). We present an overview of actions and considerations for aging dams and reservoirs that should ultimately lead to the development of an exit-strategy framework for stakeholders, researchers, and policymakers to develop proactive site-specific solutions. This framework will serve as a coarse understanding of what one could consider when developing dam and reservoir exit strategies, and hopefully, generate thorough and much-needed discussion on the future of aging dams and reservoirs.

\section{The need for proactive management of dams and reservoirs}

Proactive management for dams is usually implemented in the form of risk assessment and disaster management (Federal Emergency Management Agency 2013; Martin and Davies 2000; Stapledon et al. 2005). Specifically, emergency action plans are the policy mechanism used to prevent property damage and loss of life if an uncontrolled release of the dam occurred (Federal Emergency Management Agency 2013). Existing guidelines on dam and reservoir aging do not fall within the purview of the controlled transition of each structure but rather focus on minimizing damage for uncontrolled outcomes. The planning and maintenance process of emergency action plans requires consistent financial support to maintain effectiveness if a disaster were to occur. Limitations of financial support often result in prioritizing emergency action plans for only high hazard potential dams without consideration for dams with less extreme classifications. For example, in the USA, high hazard potential dams are defined as a dam that may result in loss of one or more human lives, regardless of economic or environmental losses. The funds required to repair the high hazard dams in the USA increased from 16 billion dollars in 2009 to approximately 18 billion dollars in 2012 (Task Committee of the Association of State Dam Safety Officials 2016). Consequently, the number of emergency action plans have increased in recent years due to a lack of funding for repairs. Considering alternative options to implement repairs, such as dam removals pose a potential opportunity to address 
aging from a proactive approach. Grabowski et al. (2018) estimated that removal costs for dams requiring repair in the USA ranged from approximately 30 million dollars to 19 billion dollars. The current state of proactive management of dams in the USA seems to reflect reactive management tendencies and still fail to provide exit opportunities and planning for dams and reservoirs.

Depending solely on a reactive management approach to address natural disasters has resulted in unnecessary loss of life and economic damage (e.g., wildfires) similar to other infrastructure disasters (e.g., bridge collapse) (Lin Moe and Pathranarakul 2006). There currently is no conceptual framework, let alone a legislative framework that adequately embraces a proactive approach to address the aging of dams and reservoirs. At best, there are proactive measures when a disaster occurs, but such plans are after the aging processes have concluded. For example, the Federal Energy Regulatory Commission (FERC) oversees licensing and inspection of hydropower dams within the USA (7\% of the dams in the National Inventory of Dams). The licensing and inspections responsibilities of the agency comprise the reactive management perspective for dam management and the scope of these responsibilities usually does not include the associated aging reservoir. The only proactive management approach used by FERC is emergency action plans that are designed to minimize loss of life and economic damage if an uncontrolled release of a dam were to occur. Unfortunately, even these emergency action plans have not been fully adopted and developed for high hazard potential dams throughout the country (U.S. Army Corps of Engineers 2018). Ensuring proactive management exists at federal but also among other political hierarchies (e.g., local, state) is necessary to reduce the loss of life and economic damages when dam and reservoir failures occur. We contend that a stronger implementation of proactive planning can reduce unfortunate impacts and vulnerability for not just people and structures but for the broader ecological systems that contain aging dams and reservoirs. Ultimately, the more dams and reservoirs that reach a timely exit through a controlled and intentional process means fewer dams and reservoirs will succumb to failure unexpectedly.

Regardless of how a dam or reservoir (e.g., aging, earthquake, terrorist act) may fail, the resulting outcome is finite and can be proactively addressed (Binder 2001). Furthermore, the compounding losses of ecosystem services provided by dams and reservoirs brought on by aging can also be proactively addressed. Emergency action plans fill the former role by proactively managing for the 'worst case' scenario for dam infrastructure. The exit strategy approach we propose fills the latter role by providing a proactive means to combating and ending the aging process before a dam or reservoir failure takes place. The ideal outcome from the exit strategy is to plan for and implement a controlled transition of the aging components in an integrated manner. The challenge in designing such a strategy is that there is no single outcome that can be considered "ideal" for dams and reservoirs that satisfy all socio-ecological systems. To the contrary, there is a broad range of how ideal outcomes can be interpreted and envisioned for a dam and reservoir. Similarly, the legislation and implementation of any proactive measures can be met with conflict or disregard (Pisaniello and McKay 2007). The fundamental priority in translating research into policy is ensuring that adaptability and scalability are implemented. Policymakers are then capable of adjusting policy so the appropriate evidence is identified, incorporated, disseminated, and utilized (Nutley et al. 2003). The challenge of this fundamental priority for proactively managing dams and reservoirs is trying to identify how to best balance scalability with specificity to ensure a controlled transition is achievable.

Poff et al. (2003) demonstrated that funders, science, and stakeholders are the critical components to further science-based policy and management of river ecosystems. Unfortunately, management of river ecosystems has failed to incorporate proactive management of dams and reservoirs (Palmer et al. 2008). Additionally, Poff et al. (2003) proposed using existing water management structures to investigate action-outcome relationships through an experimental lens. An experimental approach to management actions is now more commonly labeled as adaptive management (Allen et al. 2011) and has been successfully implemented for dams regarding environmental flows and water resource management (Arthington et al. 2006; Bunn and Arthington 2002; Richter and Thomas 2007; Richter et al. 2006). We expand from the critical components outlined by Poff et al. (2003) to a framework that specifically addresses the actions associated for the physical aging of dams and reservoirs. We also included effective planning components seen in emergency action plans for dams to legitimize the planning process of the framework as it relates to possible actions for dams and reservoirs. The goal of the exit strategy design herein is to ultimately build a scalable framework that not only incorporates the nuances of dam and reservoir actions with river management but also to allows users to tailor the framework to allow for adaptive management and sciencebased decision making.

\section{Background concepts}

\section{Actions to counteract the aging processes}

There are a variety of actions that can be implemented to extend the lifespan of dams and reservoirs, as well as actions to end the aging processes. The point in time when actions are enacted is critical to strategy development (Fig. 2). Often 




Time

Fig. 2 Conceptual representation of aging processes and responsive actions for a hypothetical dam and associated reservoir. The Y-axis for both graphs is apparent quality. Apparent quality represents the metric or combination of metrics used by stakeholders to evaluate management operations. On the X-axis is time. Both axis's have no units to best represent the general relationship between quality and time for all dams and reservoirs. The red line in the Dam Actions vs Aging graph is the quality of the dam over time, the quality of the dam is at its peak when construction has finished. The two most prevalent means for dam failure are (1) design flaw which is usually exposed within the first 5 years after construction, and (2) failure associated with aging depends on many factors but is inevitable. Blue

these points, identified as action points, are the intersection of a structure's apparent quality and the minimum desired quality, where quality represents the metric or combination region indicates the status quo for most dams around the world. Lines beginning from Dam Action Point represent types of dam actions to counteract the aging process and their effect on dam quality over time. The red dotted line in the Reservoir Actions vs Aging graph is the quality of the reservoir over time, the quality of the dam is at its peak when the reservoir has completely filled. Lines beginning from Reservoir Action Point represent types of reservoir actions to counteract the aging process and their effect on reservoir quality over time. Succeeding arrows represent future Reservoir Action Points. The Dam Action Point in the Reservoir Actions vs Aging graph demonstrates the relationship between Dam Actions and Reservoir Actions (color figure online)

of metrics used by stakeholders to evaluate management operations. Keeping at least some function is possible through these actions, but sustained feasibility is unlikely, 
resulting in a need to exit. The aging process for a dam can only be exited through dam failure or dam removal, and for a reservoir, the exit is achieved through elimination. Failure often means that the structural integrity of the dam has been compromised, resulting in the release of water from the reservoir, often suddenly. The alternative and preferable exit is to remove the dam and its reservoir under controlled circumstances. Stakeholders need to be cognizant of the reality that exit from the aging processes is inevitable, but implementing actions proactively is optional.

Discussion regarding actions on dams in disrepair seems to gravitate from dam rehabilitation on one end of the spectrum (Diloreto et al. 2017) to dam removal on the other end (Poff and Hart 2002), but these actions are not eitheror decisions. There are a variety of actions available for dams (Table 1) that managers can evaluate and implement to combat the effects of aging. Each action has its own unique physical, biological, economic, and social outcomes (Heinz Center 2002). Whether an action is suitable for a dam depends on both the feasibility of implementing the action and the considerations to potential outcomes. Similarly, actions for reservoirs (Table 2) encompass a variety of actions to slow the aging process. Sedimentation is often the primary concern for reservoir actions, but other issues such as invasive species and water quality may require alternative actions (Miranda 2017). The limiting factor in most actions is often financial capital. Implementing actions can be expensive endeavors especially if actions are expected to be conducted after the economic life span of infrastructure has ceased. Actions may also be cost prohibitive for certain types of owners (e.g., government, private) depending on the feasibility and considerations that are ideal for

Table 1 Possible actions to combat the aging process of dams

\begin{tabular}{|c|c|c|}
\hline Dam action & Definition & Example references \\
\hline No action & $\begin{array}{l}\text { No action is defined as no longer maintaining the dam for } \\
\text { any reason. The aging processes are left unmitigated, } \\
\text { and at some point, the dam will inevitably fail. This } \\
\text { action type is more common in small, privately held } \\
\text { dams designed for supporting irrigation, water supply for } \\
\text { livestock, or wildlife }\end{array}$ & Evans et al. (2000), Pisaniello and Tingey-Holyoak (2017) \\
\hline Reactive management & $\begin{array}{l}\text { Reactive management is the continued operations under the } \\
\text { status quo, where the dam is regularly inspected, and any } \\
\text { needed repairs are implemented pending funding }\end{array}$ & Bowles et al. (1999) \\
\hline Refortify & $\begin{array}{l}\text { Refortification is the alteration of the original dam design } \\
\text { to strengthen the integrity of the dam. This often involves } \\
\text { increasing the size of the dam, and thus the reservoir, by } \\
\text { building up the structural components of the dam. The } \\
\text { lifespan of the dam is prolonged, as a new state of opera- } \\
\text { tion is established. Increasing the extent of the reservoir } \\
\text { magnifies environmental and social effects on surround- } \\
\text { ing areas }\end{array}$ & Pittock and Hartmann (2011) \\
\hline Recommission & $\begin{array}{l}\text { Recommission action could be implemented to make physi- } \\
\text { cal modifications to repurpose the dam under consistent } \\
\text { and intended operation (e.g., change the structure from } \\
\text { hydropower generation to water supply as primary pur- } \\
\text { pose). This action-type differs from current management } \\
\text { in that the original dam no longer operates under the sta- } \\
\text { tus quo but is modified to create a new state of operation }\end{array}$ & Banyard et al. (1992), Pittock and Hartmann (2011) \\
\hline Partial decommission & $\begin{array}{l}\text { Partial decommission typically leaves the dam in place, but } \\
\text { gates are removed or opened permanently. Year-round } \\
\text { connectivity of the river may be possible, depending on } \\
\text { the magnitude of the decommission. In some cases, dams } \\
\text { are left in place for historical significance. Repairs on the } \\
\text { structure are not commonly performed and emergency } \\
\text { action plans are developed instead }\end{array}$ & Randle et al. (2015) \\
\hline Full decommission & $\begin{array}{l}\text { Full decommission involves complete removal of the dam } \\
\text { (American Society of Civil Engineers Task Committee } \\
\text { 1997). Natural flow regimes are restored, as well as origi- } \\
\text { nal flood conditions for the area (Heinz Center 2002). } \\
\text { This option requires the most upfront financial costs to } \\
\text { perform. Release of built up sediment is usually unavoid- } \\
\text { able and produces its own range of consequences }\end{array}$ & $\begin{array}{l}\text { Shuman (1995), Tonitto and Riha (2016), Warner and } \\
\text { Pejchar (2001) }\end{array}$ \\
\hline
\end{tabular}


Table 2 Possible actions to combat the aging process of reservoirs

\begin{tabular}{|c|c|c|}
\hline Reservoir action & Definition & Example references \\
\hline Mitigate & $\begin{array}{l}\text { Mitigation is typically an effort to reduce or slow the aging process without } \\
\text { influencing reservoir operations (Miranda, 2017). Sediment removal is a wide- } \\
\text { spread practice. Other approaches include shoreline stabilization, construct- } \\
\text { ing fringe wetlands and breakwaters. Aging processes that affect ecosystem } \\
\text { function may also require manipulations in fish communities, habitat, or water } \\
\text { quality. Specific examples may include aeration, fish barriers, nutrient seques- } \\
\text { tration, and water-level management. The water level is not typically lowered } \\
\text { during the mitigation process }\end{array}$ & Pegg et al. (2015) \\
\hline Renovate & $\begin{array}{l}\text { Renovation is more invasive toward the uses of the reservoir as it usually } \\
\text { requires the water level to be lowered resulting in a temporary interruption of } \\
\text { services provided. Many techniques are identical to the examples listed by the } \\
\text { mitigation approach but are implemented at much larger scales. Some common } \\
\text { techniques include: dredging of accumulated sediments, lake shaping and } \\
\text { habitat construction, fish-community manipulation, outflow-control modifica- } \\
\text { tions, water-quality improvements, and water-level manipulations }\end{array}$ & $\begin{array}{l}\text { Shuman (1995); Tonitto and Riha, (2016); } \\
\text { Warner and Pejchar, (2001) }\end{array}$ \\
\hline Repurpose & $\begin{array}{l}\text { When mitigation or renovation is not viable (financially, physically, socially), } \\
\text { decisions may be made to adjust or repurpose how the reservoir is used. One } \\
\text { scenario may be a change from a cool-water to a warm-water fishery, or even } \\
\text { shift from recreational angling to waterfowl hunting. Another example would } \\
\text { include a reservoir used for surface-water irrigation that would modify its } \\
\text { operations, but not its physical infrastructure to deliver water with the intent to } \\
\text { recharge groundwater. Repurposing may be as simple as accepting the fact the } \\
\text { reservoir is aging and beneficial uses are changing, thus adapting the manage- } \\
\text { ment strategy to the new objective }\end{array}$ & Miranda (2017); Schmutz and Moog (2018) \\
\hline Eliminate & $\begin{array}{l}\text { Elimination of the reservoir is only possible if the dam is decommissioned. The } \\
\text { reservoir would return to some semblance of its original riverine form and } \\
\text { much of the reservoir would be exposed for terrestrial plant growth. Elimina- } \\
\text { tion is typically implemented on smaller reservoirs, but some large reservoirs } \\
\text { have been eliminated, such as the removal of the Glines Canyon Dam, Wash- } \\
\text { ington, USA }\end{array}$ & Doyle et al. (2005) \\
\hline
\end{tabular}

the socio-ecological system. We have outlined the more common categories of actions that can be implemented to combat the aging processes for dams and reservoirs. The actions represent a general overview rather than an exhaustive attempt to identify and define all possible actions recognized at this time for aging dams and reservoirs. Users of the framework are advised to research costs of actions specific to their dam and reservoir as costs will vary by location. The following section expands on the fundamental concerns associated for both dam and reservoir actions from a feasibility and considerations standpoint.

\section{Feasibility for actions}

Scale, engineering, and public health and safety are all non-negotiable factors that must be considered when determining which actions are appropriate. Scale refers to the size of the dam and reservoir, as well as the time needed to execute actions. Spatial and temporal scales emphasize the feasibility of actions in relation to the economic cost. For example, dredging a small reservoir such as Wagon Train Reservoir, Nebraska, USA (127 ha) is economically feasible because the time, effort, and cost required is relatively small; alternatively, dredging the entirety of a large reservoir such as Lake Mead, Nevada, USA (64,000 ha) is well beyond an economically feasible action given the scale at which the action would be implemented. A medium reservoir such as Tuttle Creek Lake, Kansas, USA (5000 ha) may have multiple, feasible strategies available and may require studies to identify the most cost-effective solution (Smith et al. 2013).

Engineering comprises two features dam location and dam material. Dam location is particularly important for cases, where refortification may be the optimal action as only certain locations with the appropriate geology and other physical characteristics, can support a larger dam. The frequency, duration, and periodicity of hydrological events in relation to dam location must also be considered when choosing an exit strategy. If one dam is removed, will a downstream dam be able to endure more extreme hydrological events? Material refers to the actual makeup of the dam: earthen, rolled compacted concrete, rockfill, or concrete. Each material type will require different costs for each action option. Scale will also influence the total cost to execute an action. Dam type and mode of operation are associated with engineering feasibility and are often site specific (McManamay et al. 2016; Poff and Hart 2002). 
Dams with the primary purpose of flood control are largely responsible for public health and safety. Removal of this type of dam is usually not possible because downstream development may be prevalent in the floodplain. Allowing for natural flood conditions would likely have severe economic costs and be a threat to public safety. Flood-mitigation construction in the form of dikes and levees can minimize the loss of physical structure and the safety risks downstream of the decommissioned dam, but this is also a costly option as these structures would need continual upkeep and management (Pinter 2005). Returning a dam and reservoir system to a free-flowing river comes with inherent risks to people associated with downstream flooding.

\section{Considerations}

Biophysical, socioeconomic, and geopolitical domains are all negotiable factors that could be considered when determining which of the management actions are appropriate. The biophysical domain refers to the interactions and outcomes of anthropogenically driven modifications of abiotic and biotic factors (Füssel 2007; Garandeau et al. 2014; Tullos et al. 2013). Depending on the action implemented, there are two major areas of concern that stakeholders can consider: hydrologic connectivity and ecosystem health. Restoring hydrologic connectivity and natural flow conditions in riverine systems may benefit native aquatic species dependent on free-flowing systems but may also provide expansion opportunities for invasive species (Rahel 2007). The initial transition to a free-flowing system involves the flushing of accumulated reservoir sediment downstream, often laden with nutrients and potentially toxic elements. The combination of biological, chemical, and physical changes poses opportunities to improve or diminish aquatic ecosystem health. Similarly, dewatering of a reservoir exposes areas of the floodplain, prompting the growth of native or invasive terrestrial plants (Stanley and Doyle 2003). Implementation of any action has the potential to change ecosystem health for adjacent terrestrial ecosystems and connected aquatic ecosystems. Furthermore, the expected ecological response of any action will be influenced by the watershed's geomorphological characteristics (Doyle et al. 2005; Kondolf 1997; Kondolf et al. 2014; Schmitz et al. 2009). Changes in the watershed such as land use may prevent a river from returning to pre-dam conditions regardless of the action implemented.

The socioeconomic domain focuses on the human dimensions (i.e., values, attitudes, beliefs) and economic consequences (i.e., social capital, human capital) of dams and reservoirs to surrounding communities (Tilt et al. 2009). Values can usually be differentiated between use values (e.g., frequency of recreational activities, production of a fishery, or megawatts of hydroelectric power produced) or non-use values (e.g., aesthetic appeal, nostalgia, or historical significance). A variety of use and non-use value perspectives collectively form community values and drive associated economies. Implementation of an action causes a distribution of gains and losses that will inevitably introduce conflict between stakeholders (Born et al. 1998). For example, Lewis et al. (2008) demonstrated that the removal of the Edwards Dam in Augusta, Maine influenced economic values of real estate properties surrounding dam sites. The socioeconomic aspect of dam and reservoir actions will affect public involvement and the resulting decision-making process for better or for worse. Identifying and incorporating appropriate stakeholders in the exit-strategy process and disseminating sciencebased evidence among stakeholders provide opportunities to guide management actions, establish accountability, and improve decision making (Johnson and Graber 2002). Realizing that stakeholders are not static but rather dynamic groups that can change positions when presented with new information will be necessary to assess values and economic impacts (Born et al. 1998). Appeasing all stakeholders both from human dimensions and economic perspectives will always remain extremely challenging.

The geopolitical domain involves stakeholders and the legal mechanisms that shape the behavior and dialogue of legal interactions. Mechanisms consider the laws, statutes, and legislation that are developed and enforced by government entities. Stakeholders in the legal arena can be described as advocates, opponents, authority, or management. Advocates and opponents represent the division of stakeholders that respectively support or oppose a proposed action. The composition of advocates and opponents will likely be from a wide array of interest groups with potentially different desired outcomes (Nüsser 2003). Authority is attributed to stakeholders that possess legal precedence or own dam infrastructure. Stakeholders responsible for dam and reservoir operations should be identified as management. The discourse between stakeholders and legal mechanisms are dependent on multiple scales (e.g., local, state, federal) each requiring a specific process with associated timelines (Bowman 2002). The legal interactions between stakeholders are often restricted to existing mechanisms and hierarchies that correspond to the encompassing administrative boundaries. How legal interactions transpire can largely affect available actions and the time required to implement a proposed action. For example, the Oroville spillway collapse has been clouded with accusations of negligence and ignorance among multiple responsible jurisdictions resulting in time-consuming lawsuits (France et al. 2018; Hollins et al. 2018). 


\section{An exit-strategy framework to aid in the design for controlled transitions of aging dams and reservoirs}

The inherent complexities described herein and elsewhere almost naturally demand a logical means to process the possible actions and outcomes. One common means to put structure to such decisions is developing priority or decision frameworks to help stakeholders navigate the process. The emphasis of our framework (Fig. 3) is to inform the design of a controlled transition of the dam and reservoir to exit the aging process. Available (and possible) actions, feasibility, and considerations contribute to the bulk of the framework as these components most directly interact with the aging process. For the exit-strategy framework to provide an informative and realistic perspective of how controlled transitions can occur, evaluation of initial requirements is necessary to the design process and to ultimately exit the aging process.

The initial requirements (Fig. 3, represented as overlapping circles) are the foundational components to inform design constraints and address existing management operation gaps. These components are: risk assessment and monitoring data, agreed-upon thresholds and action points, appropriate funding, and leadership and stakeholder involvement. Most management regimes for large dams have some semblance of all four components but may not have evaluated their relevance and application to an exit strategy. However, many small dams throughout the USA have none of these components and will remain in such state unless a regulatory system or other incentives are implemented (Pittock and Hartmann, 2011). The grouping of these components emphasizes the dependency of one another to provide the most informative collection of resources available and resources needed to navigate the exit strategy. Definitions of the initial requirement components are:

- Risk assessment and monitoring data provide stakeholders information regarding the quality of the dam and reservoir in relation to the aging processes and action points (Federal Emergency Management Agency 2012). Such information can vary on how it is collected, regardless the data and analyses are critical to identifying the relationship between the structure's quality and minimum quality thresholds (Brownjohn 2007; Swain et al. 1998). Results from risk assessment and monitoring data can also provide stakeholders rates at which aging is occurring for the dam and reservoir.

- Agreed-upon thresholds and action points represent the identification and agreement of minimum desired quality of the dam or reservoir and the point at which the quality of the "structure" warrants an action. Depending on the age of the dam or reservoir, multiple action points and thresholds may exist for a single structure.

- Lack of funding is more the norm than the exception when considering action options for dams and reservoirs (Stedinger et al. 1996) thus appropriate funding is the identification of available funds needed for an action to be implemented. In cases where certain initial requirements are suboptimal, identifying appropriate funding to address initial requirement shortcomings can be applied here as well.

- Leadership and stakeholder involvements are the identification and retention of decision-makers and input providers throughout the exit strategy. Incorporating stakeholders that are knowledgeable in the feasibility and considerations of the dam and reservoir will help optimize an exit strategy. A fair representation of stakeholders involved at the leadership level may help alleviate litigation.

Evaluation of initial requirements allows stakeholders to readily identify (1) issues associated with the dam and reservoir and (2) potential solutions to address those issues. Assuming stakeholders agree on actions needed, actions can be analyzed for their feasibility and considerations. Recognize that these components are implemented in parallel; this is to reflect the interactive nature of feasibility and considerations, considerations will affect the feasibility of actions and feasibility will affect considerations (Fig. 3). Stakeholders will need to identify what factors are influencing the feasibility of actions the most. If this information is not readily available, then a feasibility study could be completed. Additionally, stakeholders may need to investigate what considerations are of the highest priority. For example, is restoring a migration corridor for an anadromous species more important to the adjacent community than the electricity generated from the hydropower turbines? The dialogue among stakeholders regarding feasibility and considerations should be well organized and methodical: compiling existing research, conducting analyses and studies, disseminating findings, and ultimately deciding on a path forward for the system. The product of this evaluation period is to create a "short list" of possible actions that reflect the most important aspects of feasibility and considerations regarding the dam and reservoir, and its stakeholders. These possible actions should be actions that can be realistically implemented by accountable stakeholders. Assigning accountability may be limited to the owners and managers for the dam as the implementation of an action will likely fall on these stakeholders. The assignment of accountability becomes more difficult in situations where no apparent stakeholder has authority over the dam. Such issues apply to the more 
Fig. 3 Conceptual exit-strategy framework for aging dams and reservoirs. Initial requirements (overlapping circles) represent components that a design team has available. The remainder of the exit-strategy process outlines individual components that need to be evaluated. Leveraging resources from the initial requirements will inform much of this process. The feedback arrow represents a path if exit from the aging processes is not obtained for both dam and reservoir from an exit strategy

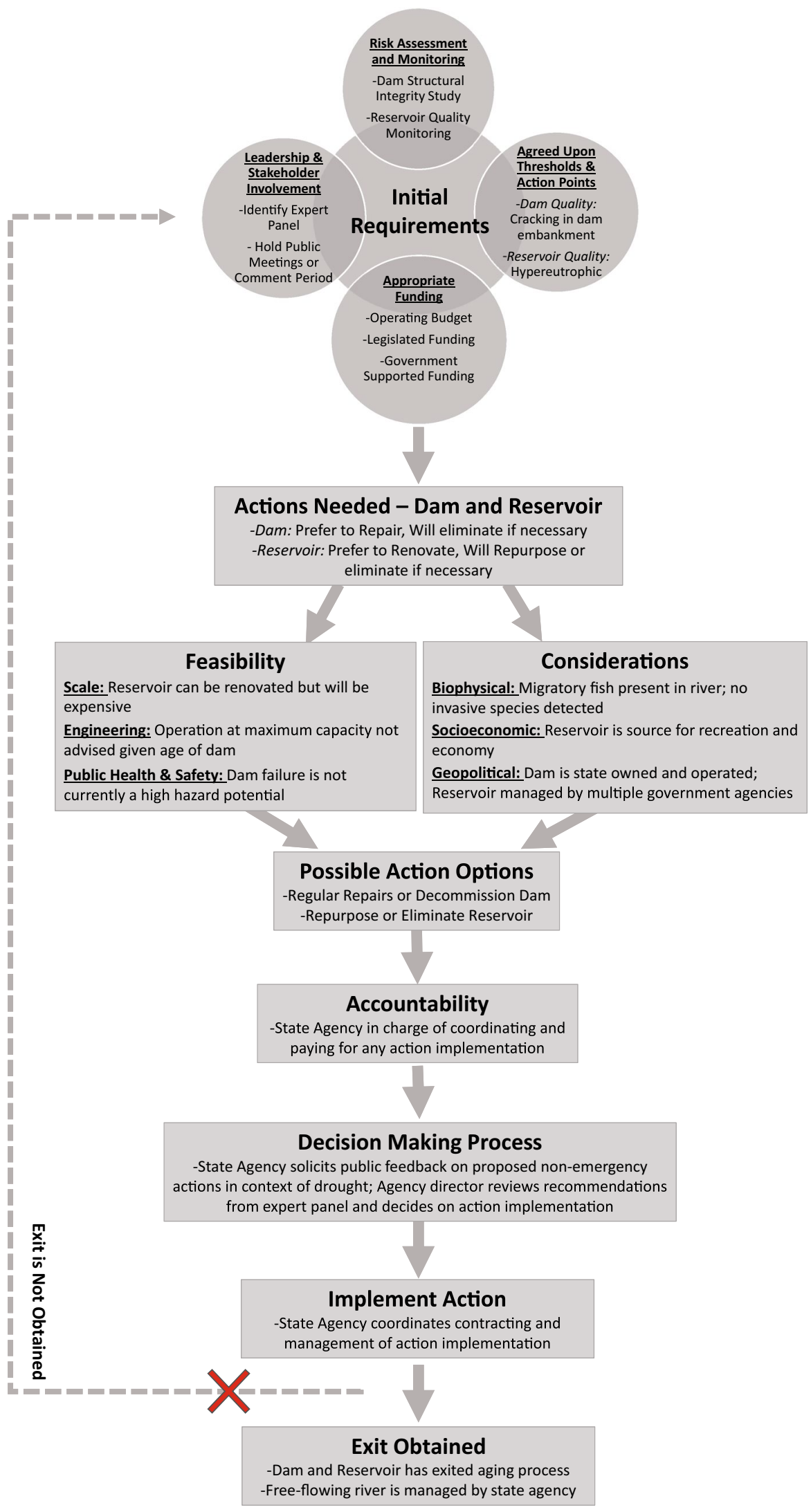


prevalent, but smaller private dams and reservoirs surrounded by multiple land owners.

A decision-making process is the order of steps an accountable stakeholder must make to finalize a decision on a proposed action. The individual steps for the decisionmaking processes will depend on the type of organization the accountable stakeholder represents (e.g., government, private). If the decision-making process results in an approval for a proposed action, implementation can begin. In cases where a proposed action is denied, the decision-making process will have to continue until a conclusion is reached. Implementation of an action can be a complex endeavor involving substantial amounts of capital and stakeholder coordination. For example, the removal of a dam will likely be done by a contractor and this process can take months depending on the size and type of the dam. During the damremoval process, constant communication is essential to prevent public-safety disasters (e.g., flooding). Deciding on the allocations of appropriate funding to the implementation step will vary by exit strategy. An important distinction of the implementation action step is the presence of a feedback loop. Its purpose is to require continued development of the exit strategy if an exit has not occurred following the implementation of the action. To reiterate, if the dam and reservoir continue to exist, there are still aging issues to address. The only way to reach the exit-obtained step is to implement an action, or multiple actions, that results in an exit of the aging processes for both the dam and reservoir.

\section{Hypothetical example of framework in action}

Climate change is one factor, among many, that can disturb the stability of a social-ecological system as well as its associated infrastructure. Climate change has already been identified as a catalyst for more localized extreme weather events that may exceed physical capabilities of aging dams. Climate change may also accelerate the aging process for reservoirs where continual precipitation events can increase sedimentation rates for a reservoir, thus accelerating the aging process. Alternatively, climate change may also involve droughts which may lower water levels and reduce capacity of a reservoir. The comprehensive effects of climate change on dam and reservoir aging as well as the actions associated with such infrastructure is an understudied but critical topic for dam and reservoir management actions (Bellmore et al. 2017; Doyle et al. 2005; Fluixá-Sanmartín et al. 2018). However, we use the potential influence of climate change as a backdrop to demonstrate how issues surrounding the aging process could be incorporated into a hypothetical dam and reservoir exit strategy.

In this hypothetical example, the surrounding landscape of an earthen embankment dam and medium reservoir is dominated by row-crop agriculture that relies on the reservoir for irrigation. The dam serves multiple functions but is primarily designed for (1) retaining water for irrigation, (2) managing for flood waters, and (3) providing recreation opportunities. The dam and reservoir have passed their designed life-span, the dam shows no sign of structural flaws and the reservoir has not become completely filled with sediment. Climate and weather projections suggest droughts will become more prevalent in the following century for the region. In recent years, the current management of the dam has had to retain more water during spring runoff to satisfy irrigation demands during peak growing season. Increased water retention is often reaching maximum engineered capacity for the aging dam. Downstream water users are upset by their water loss as their region also depends on flows to recharge their own reservoir to support agriculture. The dam and reservoir managers worry that releasing more water for downstream users may limit immediate irrigation capability. Managers also worry that a lower reservoir level may increase the possibility of the reservoir becoming hyper-eutrophic and affect the recreational opportunities currently enjoyed. Dam and reservoir managers reach out to exit strategy designers to address the growing issues for their aging dam and reservoir.

The strategy development process begins with exit strategy designers assisting the dam and reservoir managers in fully understanding the initial requirements for this system and includes establishing a leadership team that includes representatives from all stakeholder groups The leadership team compiles existing results for structural integrity of the dam and water quality and sedimentation within the reservoir to assess encroaching action points for the dam and reservoir. The primary anticipated action point for the dam is a flaw to structural integrity. The primary anticipated action point for the reservoir is nutrient and sediment loading. Current funding only provides sufficient funds to perform regular maintenance of the dam.

The framework in Fig. 3 then moves the process to addressing action points. The leadership team might recognize that retaining spring runoff water is necessary to support nearby agriculture but operating the dam at maximum retention each spring is a risky action given the age of the dam. The team could further realize the nutrient status for the reservoir may reach hyper-eutrophic conditions if peak irrigation demand occurs during a drought. If drought conditions become more persistent, then prioritizing for flood management may not be as necessary for the long term. The leadership team can thus start a dialogue on new flow regimens in the context of a prevalent drought system that would satisfy agriculture throughout the region. In our example, we present that the leadership team identified the following possible actions for the dam and reservoir in response to a different climate: 
1. If drought conditions can be managed by a specific operation of the dam and reservoir

a. The dam requires regular repairs to retain water and release water for downstream users

b. The reservoir needs to be renovated to increase capacity of the reservoir without necessarily approaching an unsafe maximum retention level.

2. If drought conditions cannot be managed by a specific operation of the dam and reservoir

a. The dam needs to be decommissioned (full or partial)

b. The reservoir needs to be repurposed or eliminated

3. If the dam shows signs of impending structural failure due to consequences of aging

a. The dam needs to be fully decommissioned

b. The reservoir needs to be eliminated

The above possible actions should be evaluated in concert with numerous aspects of both logistical feasibilities (e.g., scale, engineering, and public health and safety) and socio-ecological considerations (e.g., biophysical, socioeconomic, and geopolitical). Dam and reservoir actions under the "drought is manageable" scenario are both feasible but substantial capital is necessary for the short-term to implement a reservoir renovation and in the long term for ongoing maintenance. Considerations for the renovation would require approval from regulating agencies, so impacts to the biophysical aspects of the reservoir and adjacent landscape are minimized. Dam and reservoir actions under the "drought is not manageable" scenario are also feasible and are less expensive than the previous scenario actions. Renewed connectivity of the river is anticipated to help migratory fish in the system; whereas, loss of the reservoir would require local agriculture interests to largely depend on groundwater for irrigation and recreational opportunities in the reservoir may be eliminated. The last scenario is included by designers to account for any unexpected structural issues that may arise in the future given the age of the dam. Exit strategy designers solicit input from adjacent communities and experts regarding the feasibility and considerations for the possible actions needed.

Given ongoing feedback from stakeholders and experts, designers and the leadership team identify that the current exit strategy is suitable if financial remediation can be agreed upon between stakeholders. The leadership team then identifies (1) which managers are responsible for implementing actions, (2) the decision-making process on how to finalize an action, and (3) how to coordinate and implement an action. Designers then identify if further exit planning is needed for the dam and reservoir. Exit from the aging process will likely be achieved in a controlled transition under the current strategy because both dam and reservoir are likely to be eliminated in a proactive manner. The situation in the absence of this framework supposes that having no plan in place will only invoke reactionary responses when a crisis occurs. Such responses can lead to ill-conceived plans that may be substantially more costly in the long run over an approach that has been more thoroughly vetted (France et al. 2018).

\section{Discussion}

Embracing a proactive approach to the aging of all forms of infrastructure is a challenge (Cagle 2003; Halfawy 2008). Overcoming such a challenge for dams and reservoirs requires a conceptual framework that adequately links infrastructure actions to realistic socio-ecological outcomes in a preemptive way (Wescoat and Halvorson 2000; Willems et al. 2018). Our conceptual exit strategy provides that link and was designed to prioritize not only simplicity and scalability, but to also integrate the fundamental components seen in emergency action plans for dams and river-systems management. We anticipate a variety of users will benefit from this framework in the following ways (1) policy makers have a blueprint to design funding mechanisms and exit strategy legislation for dam and reservoir actions, (2) managers can better prioritize management actions to prevent the negative outcomes of aging dams and reservoirs, (3) stakeholders that depend on the ecosystem services provided by their dam and reservoir can anticipate and proactively address large scale changes to their socio-ecological system, and 4) researchers can investigate tradeoffs of varying exit strategies from a case-study perspective (Bednarek 2001).

Financial uncertainties and shortages will continue to make reactive management a dangerous proposition for aging dams and reservoirs. Additionally, controversy is a de facto characteristic associated with any change associated with dams and reservoirs regardless of the management paradigm implemented, resulting in costly lawsuits and lost time. Our exit-strategy framework has broad-scale applicability but does not circumvent these common limitations associated with adopting and implementing policy. Effective uptake of the framework requires financial capital to be implemented and the associated costs will depend largely on the unique characteristics of the dam and reservoir, surrounding socio-ecological systems, and encompassing governance. Recent studies have outlined approaches to help prioritize management associated with dams and reservoirs so capital can be applied more effectively (Choi et al. 2018; Hoenke et al. 2014; McKay et al. 2017). Application of our proposed framework will likely face controversy just as new 
dam development proposals do (Jorgensen and Renofalt 2013; Warner and Pejchar 2001). We contend that structuring decision making for dams and reservoirs in a proactive manner may help reduce controversy by ensuring decisions have an opportunity for both decision-makers and affected populations to be informed in a timely manner instead of under urgent timelines seen in reactive management.

Strengthening the link between exit strategies for dams, reservoirs, and the broader socio-ecological systems is a potential future direction for research. Poff and Hart (2002) provided an overview on how dams vary and how adaptive management can capitalize on these unique traits to learn more about the science of dam removal. Our overview of dam and reservoir actions highlight that the science of dam removal can be interpreted as the last of actions across time for a specific infrastructure. Put differently, achieving exit for a dam can take a long time, with multiple iterations of dam and reservoir actions taking place up until exit is achieved. We suggest researchers consider the plethora of dams and reservoir actions that may take place prior to exit as an opportunity to inform exit-strategy design, but also to see how variability and sequence of actions may affect the broader socio-ecological systems. If we posit the idea that variability is inherent in (1) dam and reservoir aging and (2) management actions, both aspects can and would likely affect society in a multi-faceted way. Therein lies the potential of interdisciplinary research to expand on the broad feasibility and considerations we provided above. Relevant questions that remain unanswered are (1) how will society and ecosystems adapt or react to a landscape with more dams and reservoirs achieving exit, (2) how will moving towards exit for dams and reservoirs affect the quantity and quality of associated ecosystem services over time, and (3) what pathways to exit yield greater outcomes for socioecological systems?

\section{Conclusion}

We are entering an era where we will be subjected to the more extreme consequences of dam and reservoir aging that can either be dealt with on an individual-circumstance basis with reactive behavior or alternatively approached with a more consistent, proactive mindset. Arguably, a framework for planning how to exit the status quo expectations of dams and reservoirs as they age should have been incorporated into the overall planning process at the onset of design and construction, but all is not lost. Many, if not most, systems containing dams and reservoirs are still ripe for a proactive planning/framework process to anticipate future decisions that incorporate a proactive approach. However, the window for implementing that proactive framework is closing as this and many other components of the human infrastructure near their terminus. Complacent support and acceptance to reactive management approaches has led to missed opportunities to adequately address aging of infrastructure (Grant 2001; Ho et al. 2017). The challenge remains for policymakers and researchers to develop a balanced approach to ensure sound exit strategies given the complicated nature of dams and reservoirs. Further research into these policy approaches is likely needed before larger-scale legislation can be implemented. The outcome of such work could pave the way for pro-active funding measures that reduce crisis driven spending. Specifically, long term monitoring of existing and past cases of dam and reservoir exits would provide insightful lessons learned to (1) aid in the development of future policy and (2) lay the groundwork for proactive dam management. The interdisciplinary nature of this problem also sets the stage for new ways of applied thinking. This paper aims to rejuvenate a dialogue among dam operators, reservoir managers, and users of associated systems on what needs to happen to the world's aging dams and reservoirs. There is no one-size-fits-all solution, nor should there be. Not only are there many types of engineered systems in place, but each site has unique ecological characteristics and unique needs of the local communities and regional stakeholders. Developing an exit strategy is a time-sensitive opportunity where aging can be purposefully addressed. Complacency on aging dams and reservoirs encroaches a point where society can no longer afford the associated outcomes.

Acknowledgements The ideas presented herein were developed during a graduate-level course entitled "Managed Aquatic Systems" that was taught during spring 2017. We thank Dr. Steve Miranda and two reviewers for critical and insightful comments that substantially improved the manuscript. MAP is supported by Hatch funds through the Agricultural Research Division at the University of Nebraska-Lincoln. The Nebraska Cooperative Fish and Wildlife Research Unit is jointly supported by a cooperative agreement among the U.S. Geological Survey, the Nebraska Game and Parks Commission, the University of Nebraska, the U.S. Fish and Wildlife Service, and the Wildlife Management Institute.

\section{Compliance with ethical standards}

Conflict of interest The authors declare that they have no conflict of interest.

\section{References}

Allen CR, Fontaine JJ, Pope KL, Garmestani AS (2011) Adaptive management for a turbulent future. J Environ Manag Adapt Manag Nat Resour 92:1339-1345. https://doi.org/10.1016/j. jenvman.2010.11.019

American Society of Civil Engineers Task Committee (1997) Guidelines for retirement of dams and hydroelectric facilities. ASCE, New York 
Arthington AH, Bunn SE, Poff NL, Naiman RJ (2006) The challenge of providing environmental flow rules to sustain river ecosystems. Ecol Appl 16:1311-1318

Association of State Dam Safety Officials (2019) Dam failures and incidents https://damsafety.org/dam-failures Accessed $13 \mathrm{Feb}$ 2019.

Bea RG (2017) Preliminary Root Causes Analysis of Failures of the Oroville Dam Gated Spillway. University of California Berkeley, Center for Catastrophic Risk Management, Berkeley

Bednarek A (2001) Undamming rivers: a review of the ecological impacts of dam removal. Environ Manag 27(6):803-814. https:// doi.org/10.1007/s002670010189

Bellmore JR, Duda JJ, Craig LS, Greene SL, Torgersen CE, Collins MJ, Vittum K (2017) Status and trends of dam removal research in the United States: Status and trends of dam removal research in the US. Wiley Interdiscip Rev 4:e1164. https://doi.org/10.1002/ wat 2.1164

Billington DP, Jackson DC, Melosi MV (2005) The history of large federal dams: planning, design, and construction in the era of big dams. Government Printing Office, Washington

Binder D (2001) Emergency action plans: a legal and practical blueprint failing to plan is planning to fail symposium: post-september 11 legal topics. U Pitt L Rev 63:791-814

Biswas AK, Tortajada C (2001) Development and large dams: a global perspective. Int J Water Resour Dev 17(1):9-21. https://doi. org/10.1080/07900620120025024

Born SM, Genskow KD, Filbert TL, Hernandez-Mora N, Keefer ML, White KA (1998) Socioeconomic and institutional dimensions of dam removals: the wisconsin experience. Environ Manage 22:359-370. https://doi.org/10.1007/s002679900111

Bowles DS, Anderson LR, Glover TF, Chauhan SS (1999) Understanding and managing the risks of aging dams: Principles and case studies, in: the nineteenth US Cold Annual Meeting and Lecture, Atlanta, GA.

Bowman MB (2002) Legal perspectives on dam removalthis article outlines the legal issues associated with dam removal and examines how environmental restoration activities such as dam removal fit into the existing US legal system. Bioscience 52:739-747

Brownjohn J (2007) Structural health monitoring of civil infrastructure. Philos Trans R Soc A 365:589-622. https://doi.org/10.1098/ rsta.2006.1925

Bunn SE, Arthington AH (2002) Basic principles and ecological consequences of altered flow regimes for aquatic biodiversity. Environ Manag 30:492-507. https://doi.org/10.1007/s00267-002-2737-0

Cagle RF (2003) Infrastructure asset management: an emerging direction. AACE international transactions, PM21

California Department of Water Resources (2018) Oroville Spillways Construction and Cost Estimate Update https://water.ca.gov/ News/News-Releases/2018/Sept-18/Oroville-Spillways-Const ruction-and-Cost-Estimate-Update Accessed 13 Feb 2019.

Choi JH, Yoon TH, Kim JS, Moon YI (2018) Dam rehabilitation assessment using the delphi-AHP method for adapting to climate change. J Water Resour Plann Manag 144:06017007. https://doi. org/10.1061/(ASCE)WR.1943-5452.0000877

Chunlong L, Lise C, Olden JD (2017) Heads you win, tails you lose: life-history traits predict invasion and extinction risk of the world's freshwater fishes. Aquat Conserv 27:773-779. https:// doi.org/10.1002/aqc. 2740

Datta PS, Tyagi SK (1996) Major ion chemistry of groundwater in Delhi area: chemical weathering processes and groundwater flow regime. J Geol Soc India 47:179-188

Diloreto G, Curtis S, Bennett J, Camp J, Hann S, Herrmann A, Hookham C, Kito S, Lynch O, Matteo A, McKeehan B, Merfeld P, Montgomery Mills S, Morris M, Movassaghi K, Murphy J, Neumann K, Nikolic A, Ogden M, Perrings D, Peskin R, Pierce L, Quinn C, Shelton R, Schipper M, Stahlman W, Talocco N,
Tilchin M (2017) Infrastructure report card. American Society of Civil Engineers, Reston

Dolen T (2005) Materials properties model of aging concrete (No. DSO-05-05), reclamation managing water in the west. U.S. Bureau of Reclamation, Washington

Doyle MW, Stanley EH, Orr CH, Selle AR, Sethi SA, Harbor JM (2005) Stream ecosystem response to small dam removal: lessons from the Heartland. Geomorphology 71:227-244. https:// doi.org/10.1016/j.geomorph.2004.04.011

Doyle MW, Stanley EH, Havlick DG, Kaiser MJ, Steinbach G, Graf WL, Galloway GE, Riggsbee JA (2008) Environmental science: aging infrastructure and ecosystem restoration. Science 319:286287. https://doi.org/10.1126/science. 1149852

Evans JE, Mackey SD, Gottgens JF, Gill WM (2000) Lessons from a dam failure. Ohio J Sci 100:11

Federal Emergency Management Association (2007) Emergency action planning for state regulated high-hazard potential dams. U.S. Department of Homeland Security

Federal Emergency Management Agency (2012) Summary of existing guidelines for hydrologic safety of dams. U.S. Department of Homeland Security

Federal Emergency Management Agency (2013) Federal guidelines for dam safety emergency action planning for dams. U.S. Department of Homeland Security

Fluixá-Sanmartín J, Altarejos-García L, Morales-Torres A, EscuderBueno I (2018) Review article: climate change impacts on dam safety. Nat Hazards Earth Syst Sci 18:2471-2488. https://doi. org/10.5194/nhess-18-2471-2018

Foster M, Fell R, Spannagle M (2000) The statistics of embankment dam failures and accidents. Can Geotech J 37:1000-1024. https ://doi.org/10.1139/t00-030

France J, Alvi I, Dickson P, Falvey H, Rigbey S, Trojanowski J (2018) Independent forensic team report Oroville dam spillway incident

Füssel H-M (2007) Vulnerability: a generally applicable conceptual framework for climate change research. Glob Environ Change 17:155-167. https://doi.org/10.1016/j.gloenvcha.2006.05.002

Gagnon L, Klimpt J-É, Seelos K (2002) Comparing recommendations from the World Commission on Dams and the IEA initiative on hydropower. Energy Policy 30:1299-1304. https://doi. org/10.1016/S0301-4215(02)00093-9

Garandeau R, Edwards S, Maslin M (2014) Biophysical, socioeconomic and geopolitical impacts assessments of large dams: an overview. University College London, London

Goteti G, Stachelek J (2016) Dams in the United States from the National Inventory of Dams (NID). R package version 0.2. https ://CRAN.R-project.org/package $=$ dams

Grabowski ZJ, Chang H, Granek EF (2018) Fracturing dams, fractured data: empirical trends and characteristics of existing and removed dams in the United States. River Res Appl 34:526-537. https:// doi.org/10.1002/rra.3283

Graf WL (1999) Dam nation: a geographic census of American dams and their large-scale hydrologic impacts. Water Resour Res 35:1305-1311. https://doi.org/10.1029/1999WR900016

Grant G (2001) Dam removal: panacea or Pandora for rivers? Hydrol Process 15:1531-1532

Heinz Center (2002) Dam removal: science and decision making. H. John Heinz III Center for Science, Economics, and the Environment, Washington, DC

Halfawy M (2008) Integration of municipal infrastructure asset management processes: challenges and solutions. J Comput Civil Eng 22:216-229. https://doi.org/10.1061/ (ASCE)0887-3801(2008)22:3(216)

Ho M, Lall U, Allaire M, Devineni N, Kwon HH, Pal I, Raff D, Wegner D (2017) The future role of dams in the United States of America. Water Resour Res 53:982-998. https://doi.org/10.1002/2016W R019905 
Hoenke KM, Kumar M, Batt L (2014) A GIS based approach for prioritizing dams for potential removal. Ecol Eng 64:27-36. https://doi.org/10.1016/j.ecoleng.2013.12.009

Hollins L, Eisenberg D, Seager T (2018) Risk and resilience at the Oroville dam. Infrastructures 3(4):49

Johnson SE, Graber BE (2002) Enlisting the social sciences in decisions about dam removal. Bioscience. https:// doi.org/10.1641/0006-3568(2002)052\%5b0731:ETSSI $\mathrm{D} \% 5 \mathrm{~d} 2.0 . \mathrm{CO} ; 2$

Johnson PT, Olden JD, Vander Zanden MJ (2008) Dam invaders: impoundments facilitate biological invasions into freshwaters. Front Ecol Environ 6:357-363

Jorgensen D, Renofalt BM (2013) Damned if you do, dammed if you don't: debates on dam removal in the Swedish media. Ecol Soc 18:18. https://doi.org/10.5751/ES-05364-180118

Juracek KE (2015) The aging of america's reservoirs: in-reservoir and downstream physical changes and habitat implications. J Am Water Resour Assoc 51:168-184. https://doi.org/10.1111/ jawr.12238

Kimmel BL, Groeger AW (1983) Limnological and ecological changes associated with reservoir aging (No. CONF-83061601). Oak Ridge National Lab, Oak Ridge

Kondolf GM (1997) PROFILE: hungry water: effects of dams and gravel mining on river channels. Environ Manag 21:533-551

Kondolf GM, Gao Y, Annandale GW, Morris GL, Jiang E, Zhang J, Cao Y, Carling P, Fu K, Guo Q, Hotchkiss R, Peteuil C, Sumi T, Wang H-W, Wang Z, Wei Z, Wu B, Wu C, Yang CT (2014) Sustainable sediment management in reservoirs and regulated rivers: experiences from five continents. Earth's Future 2:256280. https://doi.org/10.1002/2013EF000184

Lewis LY, Bohlen C, Wilson S (2008) Dams, dam removal, and river restoration: a hedonic property value analysis. Contemp Econ Policy 26:175-186. https://doi.org/10.111 $1 /$ j.1465-7287.2008.00100.x

Lin TM, Pathranarakul P (2006) An integrated approach to natural disaster management: public project management and its critical success factors. Disaster Prev Manag 15:396-413. https://doi. org/10.1108/09653560610669882

Martin TE, Davies MP (2000) Trends in the stewardship of tailings dams. Tailings and Waste

McKay SK, Cooper AR, Diebel MW, Elkins D, Oldford G, Roghair C, Wieferich D (2017) Informing watershed connectivity barrier prioritization decisions: a synthesis. River Res Appl 33:847862. https://doi.org/10.1002/rra.3021

McManamay RA, Oigbokie CO, Kao S-C, Bevelhimer MS (2016) Classification of US hydropower dams by their modes of operation. River Res Appl 32:1450-1468. https://doi.org/10.1002/ rra.3004

Miranda LE (2017) Reservoir fish habitat management. Lightning Press, Totowa

Miranda LE, Krogman RM (2015) Functional age as an indicator of reservoir senescence. Fisheries 40:170-176. https://doi. org/10.1080/03632415.2015.1007207

National Performance of Dams Program (2017) Dam failure loss-oflife consequences http://npdp.stanford.edu/consequences_fatal ities Accessed 13 Feb 2019.

Nüsser M (2003) Political ecology of large dams: a critical review. Petermanns Geogr Mitt 147:20-27

Nutley S, Walter I, Davies HTO (2003) From knowing to doing: a framework for understanding the evidence-into-practice agenda. Evaluation 9:125-148. https://doi.org/10.1177/1356389003 009002002

Palmer MA, Liermann CAR, Nilsson C, Flörke M, Alcamo J, Lake PS, Bond N (2008) Climate change and the world's river basins: anticipating management options. Front Ecol Environ 6:81-89
Palmieri A, Shah F, Dinar A (2001) Economics of reservoir sedimentation and sustainable management of dams. J Environ Manag 61:149-163. https://doi.org/10.1006/jema.2000.0392

Pegg MA, Pope KL, Powell LA, Turek KC, Spurgeon JJ, Stewart NT, Hogberg NP, Porath MT (2015) Reservoir rehabilitations: seeking the fountain of youth. Fisheries 40:177-181. https://doi. org/10.1080/03632415.2015.1017635

Peyras L, Royet P, Boissier D (2006) Dam ageing diagnosis and risk analysis: development of methods to support expert judgment. Can Geotech J 43:169-186. https://doi.org/10.1139/T05-096

Pinter N (2005) One step forward, two steps back on U.S. Floodplains. Science 308:207-208. https://doi.org/10.1126/science.1108411

Pisaniello JD, McKay J (2007) A tool to aid emergency managers and communities in appraising private dam safety and policy. Disasters 31:176-200. https://doi.org/10.1111/j.1467-7717.2007.01003 . $\mathrm{X}$

Pisaniello JD, Tingey-Holyoak JL (2017) Growing community developments causing 'hazard creep' downstream of farm dams, a simple and cost-effective tool to help land planners appraise flood safety. Saf Sci 97:58-72. https://doi.org/10.1016/j.ssci.2016.07.020

Pittock J, Hartmann J (2011) Taking a second look: climate change, periodic relicensing and improved management of dams. Mar Freshw Res 62:312. https://doi.org/10.1071/MF09302

Poff NL, Hart DD (2002) How dams vary and why it matters for the emerging science of dam removal. Bioscience 52:659-668

Poff NL, Allan JD, Palmer MA, Hart DD, Richter BD, Arthington AH, Rogers KH, Meyer JL, Stanford JA (2003) River flows and water wars: emerging science for environmental decision making. Front Ecol Environ 1:298-306

Rahel FJ (2007) Biogeographic barriers, connectivity and homogenization of freshwater faunas: it's a small world after all. Freshw Biol 52:696-710

Randle T, Helper T, Edwards W, Hozer W, Krivanec C (2015) Guidelines for dam decommissioning projects. United States Society on Dams, Denver

Richter B, Thomas G (2007) Restoring environmental flows by modifying dam operations. Ecol Soc. https://doi.org/10.5751/ES-02014 $-120112$

Richter BD, Warner AT, Meyer JL, Lutz K (2006) A collaborative and adaptive process for developing environmental flow recommendations. River Res Appl 22:297-318. https://doi.org/10.1002/rra.892

Schmitz D, Blank M, Ammondt S, Patten DT (2009) Using historic aerial photography and paleohydrologic techniques to assess longterm ecological response to two Montana dam removals. J Environ Manag. https://doi.org/10.1016/j.jenvman.2008.07.028

Schmutz S, Moog O (2018) Dams: ecological impacts and management, in: riverine ecosystem management, aquatic ecology series. Springer, Cham. https://doi.org/10.1007/978-3-319-73250-3_6

Shuman JR (1995) Environmental considerations for assessing dam removal alternatives for river restoration. Regul Rivers 11:249261. https://doi.org/10.1002/rrr.3450110302

Siddiqui IH (2009) Dams and reservoirs: planning and engineering. Oxford University Press, Karachi

Sims G (1992) Dam aging. Thomas Telford Services Ltd, London

Smith C, Williams J, Nejadhashemi AP, Woznicki S, Leatherman J (2013) Cropland management versus dredging: an economic analysis of reservoir sediment management. Lake Reserv Manag 29:151-164. https://doi.org/10.1080/10402381.2013.814184

Stanley EH, Doyle MW (2003) Trading off: the ecological effects of dam removal. Front Ecol Environ 1:15-22

Stapledon D, MacGregor P, Bell G, Fell R (2005) Geotechnical engineering of dams. Taylor and Francis. https://doi.org/10.1201/ NOE0415364409

Stedinger J, Heath DC, Thompson K (1996) Risk analysis for dam safety evaluation: hydrologic risk. Defense Technical Information Center, Fort Belvoir. https://doi.org/10.21236/ADA316926 
Swain RE, David B, Dean O (1998) A framework for characterization of extreme floods for dam safety risk assessments. In: Proceedings of the 1998 USCOLD annual lecture, Buffalo, New York.

Tang Z, Engel BA, Pijanowski BC, Lim KJ (2005) Forecasting land use change and its environmental impact at a watershed scale. J Environ Manage 76:35-45

Task Committee of the Association of State Dam Safety Officials (2016) The cost of rehabilitating our nation's dams: a methodology, estimate, and proposed funding mechanisms. Association of State Dam Safety Officials

Tilt B, Braun Y, He D (2009) Social impacts of large dam projects: a comparison of international case studies and implications for best practice. J Environ Manag. https://doi.org/10.1016/j.jenvm an.2008.07.030

Tonitto C, Riha SJ (2016) Planning and implementing small dam removals: lessons learned from dam removals across the eastern United States. Sustain Water Resour Manag 2:489-507. https:// doi.org/10.1007/s40899-016-0062-7

Tullos D, Foster-Moore E, Magee D, Tilt B, Wolf A, Schmitt E, Gassert F, Kibler K (2013) Biophysical, socioeconomic, and geopolitical vulnerabilities to hydropower development on the nu river, China. Ecol Soc. https://doi.org/10.5751/ES-05465-180316

U.S Army Corps of Engineers (2018) National Inventory of Dams http://nid.usace.army.mil/ 13 Accessed Feb 2019)

Warner K, Pejchar L (2001) A river might run through it again: criteria for consideration of dam removal and interim lessons from California. Environ Manage 28:561-575. https://doi.org/10.1007/ s002670010244

Wescoat J, Halvorson S (2000) Ex post evaluation of dams and related water projects: patterns, problems, and potential. Report to the world commission on dams. https://doi.org/10.13140/ rg.2.1.1450.5840

Willems JJ, Busscher T, van den Brink M, Arts J (2018) Anticipating water infrastructure renewal: a framing perspective on organizational learning in public agencies. Environ Plann C 36:10881108. https://doi.org/10.1177/2399654417733993

World Commission on Dams (2000) Dams and development: a new framework for decision-making. Earthscan, London

Banyard JK, Coxon RE, Johnston TA (1992) Carsington ReservoirReconstruction of the Dam. In: Proceedings of the Institution of Civil Engineers Civil Engineering https://doi.org/10.1680/icien .1992 .20280

Fahlbusch H (2009) Early dams. In: Proceedings of the Institution of Civil Engineers Engineering History and Heritage. https://doi. org/10.1680/ehh2009.162.1.13

Zamarrón-Mieza I, Yepes V, Moreno-Jiménez JM (2017) A systematic review of application of multi-criteria decision analysis for aging-dam management. J Clean Prod 147:217-230. https://doi. org/10.1016/j.jclepro.2017.01.092

Zarfl C, Lumsdon AE, Berlekamp J, Tydecks L, Tockner K (2015) A global boom in hydropower dam construction. Aquat Sci 77(1):161-170. https://doi.org/10.1007/s00027-014-0377-0

Publisher's Note Springer Nature remains neutral with regard to jurisdictional claims in published maps and institutional affiliations. 